\begin{tabular}{ll}
\hline 原 & 著 \\
\hline
\end{tabular}

\title{
歯性上顎洞炎の根尖病巣についての画像的検討
}

\author{
武田 桃子 ${ }^{1)}$, 森 恵莉 ${ }^{1}{ }^{3}$, 尾上 薰 ${ }^{2}$, \\ 飯村 慈朗 ${ }^{3)}$, 波多野 篤 ${ }^{1)}$, 尾尻 博也 ${ }^{4)}$, \\ 鴻 信義 ${ }^{3)}$ \\ ${ }^{1)}$ 東京慈恵会医科大学附属第三病院耳鼻咽喉科 \\ ${ }^{2)}$ 東京慈恵会医科大学附属第三病院放射線科 \\ ${ }^{3}$ 東京慈恵会医科大学耳鼻咽㑨科学教室 \\ ${ }^{4)}$ 東京慈恵会医科大学放射線医学講座
}

【はじめに】歯性上顎洞炎は日常でよく遭遇する副鼻垫炎のひとつである。歯性上顎洞炎の原因歯を早期発見 し，早期の歯科治療介入ができれば，歯性上顎洞炎の遷延化や急性増悪を予防することが可能となる。耳鼻咽 喉科医は副鼻脉Computed Tomography $(\mathrm{CT})$ を見る機会は多いが, 根尖周囲の病変に注目する機会は少ない。 今回我々は, 副鼻腔CTにおいて根尖病巣に注目して評価をし, また歯性上顎洞炎の歯科治療の介入の有無につ いて調べたので報告する。

【方法】平成 24 年 10 月〜平成 26 年 5 月（20か月間）に当院当科で副鼻腔CTを施行した 1,112 例を対象とした。副 鼻腔CTに抢いて(1)上顎歯の根尖病巣, (2)上顎歯と上顎洞との交通, (3)上顎洞陰影の 3 項目を有するものを調 べ, すべてを満たすものを本検討での歯性上顎洞炎の画像診断基準とし, 詳細に根尖病変を確認し, 歯科治療 の介入の有無などの患者背景を調べた。

【結果】画像上副鼻胫陰影を認めたのは882例で，その内歯性上顎洞炎と診断された患者は169例（19.1\%）で あった。受診時に歯科治療介入が確認できた患者は $12.4 \%$ （21/169）であった。

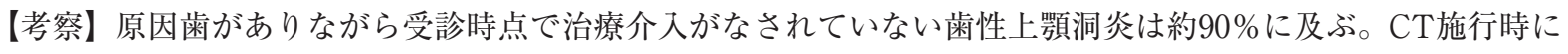
副鼻腔陰影に加えて, 上顎歯の根尖病巣の有無を確認し, 治療介入を積極的に促すことで歯性上顎洞炎遷延化 や，急性増悪の予防ができるのではないかと考えた。

キーワード：歯性上顎洞炎，根尖病巣，根管治療

\section{A Radiological Study of Periapical Disease and Odontogenic Maxillary Sinusitis}

\section{Momoko Takeda $^{1)}$, Eri Mori ${ }^{1,3)}$, Kaoru Onoue ${ }^{2)}$, Jiro Iimura ${ }^{3)}$,} Atsushi Hatano ${ }^{1)}$, Hiroya Ojiri ${ }^{4)}$, Nobuyoshi Otori ${ }^{3)}$

${ }^{1)}$ Department of Otorhinolaryngology, The Jikei Daisan Hospital

${ }^{2}$ Department of Radiology, The Jikei Daisan Hospital

${ }^{3}$ Department of Otorhinolaryngology, The Jikei University School of Medicine

${ }^{4}$ Department of Radiology, The Jikei University School of Medicine 
[Introduction] Odontogenic maxillary sinusitis (OMS) is a common type of sinusitis. However, the change to OMS can be prevented with early detection of periapical disease of the upper teeth and early dental therapeutic intervention. We suspect that routine assessment of periapical disease of the upper teeth with computed tomography $(\mathrm{CT})$ of the sinus would be useful for preventing and shortening the duration of OMS. Although OMS is usually diagnosed by otorhinolaryngologists, they can overlook periapical disease of the upper teeth. In this study, we evaluated the periapical disease of the upper teeth on the basis of detailed CT scans to determine whether patients with OMS had previously undergone dental treatment.

[Methods] A total of 1,112 patients underwent sinus CT examinations from October 2012 through May 2014 at our hospital. On sinus CT images, we searched for periapical disease of the upper teeth, root apices of the upper teeth opening to the maxillary sinus, and shadows of the maxillary sinuses. OMS were diagnosed when patients met all criteria. We examined the rates of periapical lesions of the upper teeth and a history of dental treatment and patient's characteristics.

[Results] A total of $882(79.3 \%)$ of the 1,112 patients had shadows of sinuses, and 169 (19.1\%) patients had odontogenic maxillary sinusitis diagnosed with radiological findings. Dental treatment had been received by only $12.4 \%$ of the patients (21 of 169$)$.

[Conclusion] We believe that a routine assessment of the periapical disease of the upper teeth by sinus CT might be useful for preventing the change from periapical disease to OMS.

Key words : odontogenic maxillary sinusitis, periapical disease, dental root therapy

（2015年12月 22 日受稿, 2016年 3 月 1 日受理)

\section{はじめに}

歯性上顎洞炎は副鼻腔炎の約 $10 \%$ に存在し ${ }^{1,2)}$, 歯根部 の炎症が上顎洞内に波及し鼻汁, 後鼻漏, 鼻閉, 悪臭, 煩部痛等の臨床症状をきたす疾患である。診断は臨床症 状, 原因歯の存在, 画像診断で総合的に診断される ${ }^{3)}$ 。未 処置の䠘歯, 歯原性異物, 不適切な根管処置 (図 1 ), こ れらが原因となる根尖病巣（図 2 ）や，インプラント治 療 (図 3 ) が原因 ${ }^{4}$ となるといわれている。不適切な根管 処置もしくは未処置の齸歯が原因である歯性上顎洞炎 の，原因歯に対しての治療法は確立されておらず，統一 された見解はない ${ }^{5,6)}$ 。現段階での保存的加療として耳鼻 咽喉科では通常の副鼻腔炎に準じた治療を，歯科では根 尖病巣を伴う場合には根管治療による治療が一般的であ る。一方, 外来通院で行う保存加療に効果がみられない 場合には抜歯や, 内視鏡下鼻内副鼻腔手術（Endoscopic Sinus Surgery: ESS) の適応となる ${ }^{7)}$ 。歯性上顎洞炎を未 治療のまま放置した場合, 治療は遷延化し, いずれは篩 骨洞や前頭洞等へ炎症が波及し，眼窩内合併症や頭蓋内 合併症をきたす場合もある。最終的に抜歯もESSも必要 となるケースも少なくない。そのため, 歯と上顎洞との病 態を正確に診断し，適切な時期での治療介入が望ましい。

CT検査は歯と上顎洞の位置関係を明瞭に描出するの

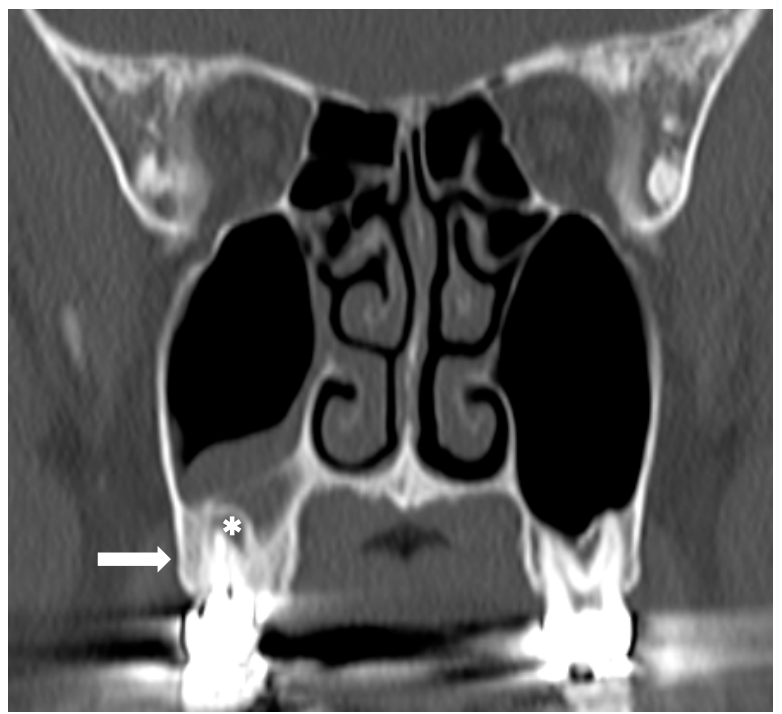

図 1 不適切な根管処置 症例 : 42歳男性, 主訴：悪臭・鼻 閉。右上顎歯の根管処置が不十分なため根尖病巣 $(*)$ を伴っている。根管処置で歯髄はCT上白色管状構造物 (矢印) として認める。

にもっとも有用な検査である ${ }^{1)}$ 。我々耳鼻咽喉科医は副 鼻腔CTを見る機会は多いが，多くは副鼻腔の軟部陰影 に目が行き，副鼻腔外の根尖周囲に注目する機会は少な いのではないかと予想される。その為歯科治療の介入を 


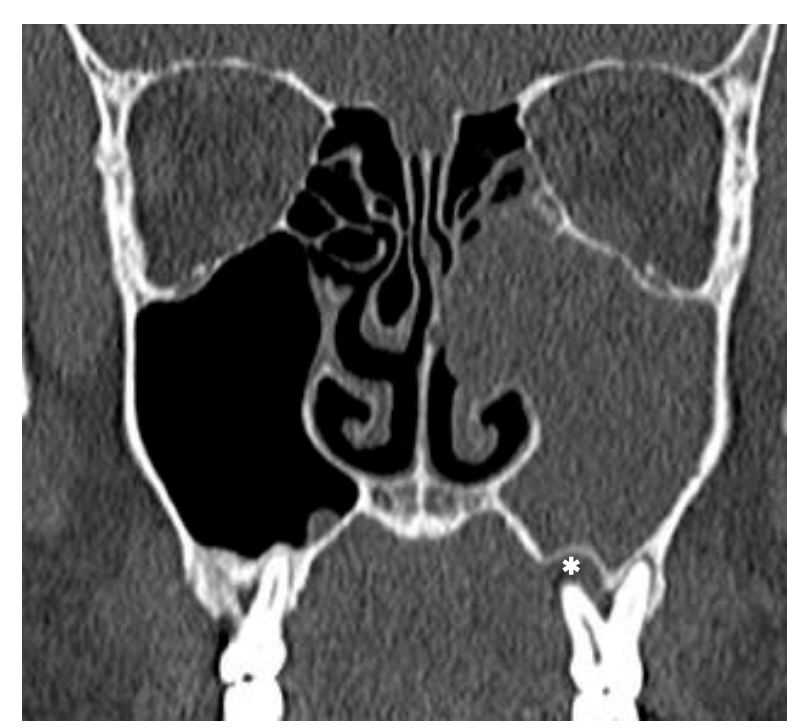

図2 根尖病巣 症例 : 46歳男性, 主訴：悪臭・鼻汁。根尖 部に歯根垫の拡大 $(*)$ を認める。

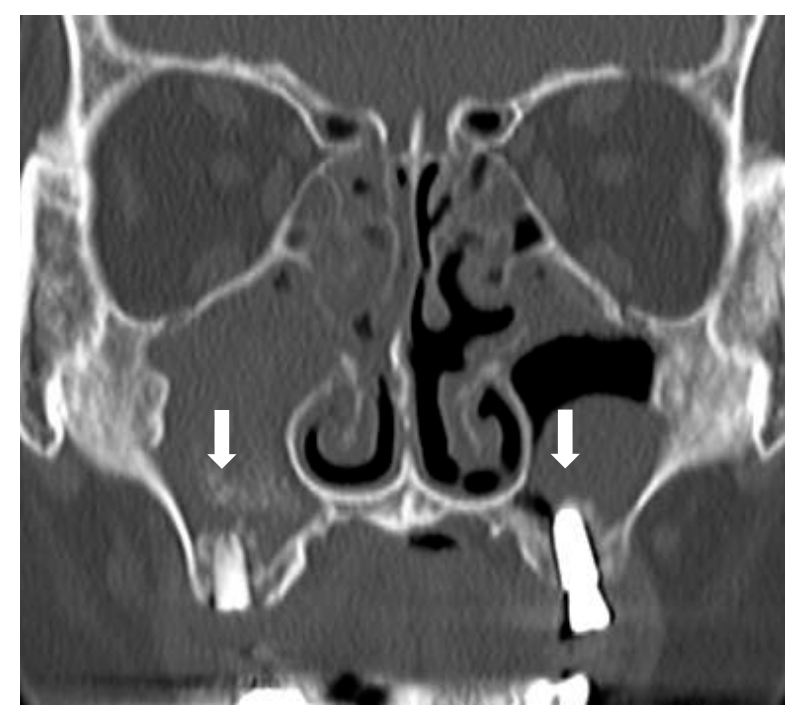

図 3 インプラント治療 症例：70歳女性, 主訴: 右煩部痛・ 鼻汁・悪臭・鼻閉。両側インプラント (矢印) 挿入後 に歯性上顎洞炎を発症している。

促す機会を逸している可能性が示唆される。今回我々 は, 副鼻垫CT画像において歯性上顎洞炎における根尖病 巣に注目して評価をし，また歯科治療の介入の有無につ いて調べたので報告する。

\section{対象と方法}

平成24年10月～平成 26 年 5 月（20か月間）に当院当科 で副鼻腔CTを施行した1,112例を対象とし，根尖部周囲 の病変を詳細に確認し，歯科治療の介入の有無や患者背 景を調べた。副鼻膛CTにおいては, 当院で使用されてい

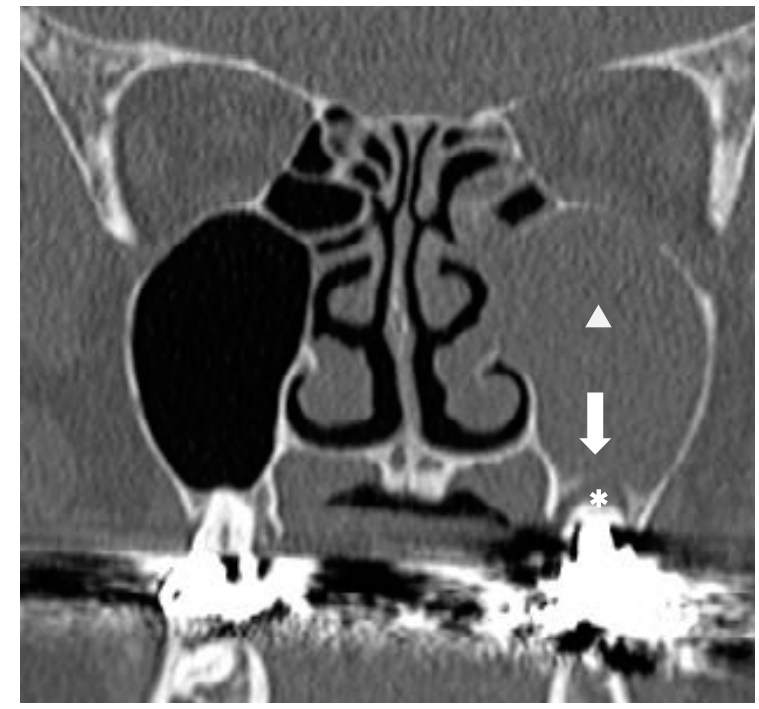

図4 歯性上顎洞炎の画像所見 症例 : 56歳女性, 主訴; 左 煩部痛。根尖病巣 $(*)$-上顎洞との交通 (矢印) - 上 顎洞陰影（山）すべてを伴っている。

る製品名: SOMATOM Definition As, 会社名: SIEMENS, 撮影条件64列/128スライスCT（管電圧 $100 \mathrm{KV}$ ，管電流 $200 \mathrm{~mA}$ ), を使用した。水平断（骨・軟部条件）・冠状断 (骨条件) ・ 矢状断（骨条件）すべてを用いて根尖病巣を 評価した。なお，水平断は骨・軟部条件ともスライス厚 $2 \mathrm{~mm}$, スライス間隔なし, 水平断および矢状断はスライ ス厚 $1 \mathrm{~mm}$ ，スライス間隔 $2 \mathrm{~mm}$ とした。また副鼻腔CTで (1)上顎歯の根尖病巣，(2)上顎歯と上顎洞との交通，(3)上 顎洞陰影の 3 項目（図 1〜4）の有無をそれぞれ調べ, すべてを満たす患者を歯性上顎洞炎と診断した ${ }^{8)}$ 。(2)に ついては, 根尖病巣を伴う骨溶解像（図 5 ）ならびに, 根尖病巣を伴わないが上顎洞内に歯根部が突出している 場合（図 6 ）も，上顎洞との交通ありと判断した。尚, 評価及び判定は特定された複数の耳鼻咽喉科専門医なら びに放射線科専門医で行った。上顎洞との交通を有する 歯科材料等異物迷入 (図 7 ) ·含歯性囊胞も含め, また過 去にCaldwell-Luc手術の既往・術後性上顎囊胞を有する 患者は除外とした。CT画像より, 根尖病巣が原因となる 歯性上䫈洞炎と診断された患者に対し，年齢・性別・合 併症・治療歴・喫煙歴・原因歯・治療歴（歯科治療を含 む）の有無について調べた。

\section{結 果}

1,112例のうち，副鼻腔陰影を認めた患者は882例 （79.3\%）であった。副鼻腔陰影を認めた 882 例の上顎洞 周辺のCT所見にて, (1)上顎歯の根尖病巣を有するのは 354名 $(40.1 \%)$ ，(2)上顎洞と交通を有するのは238名 


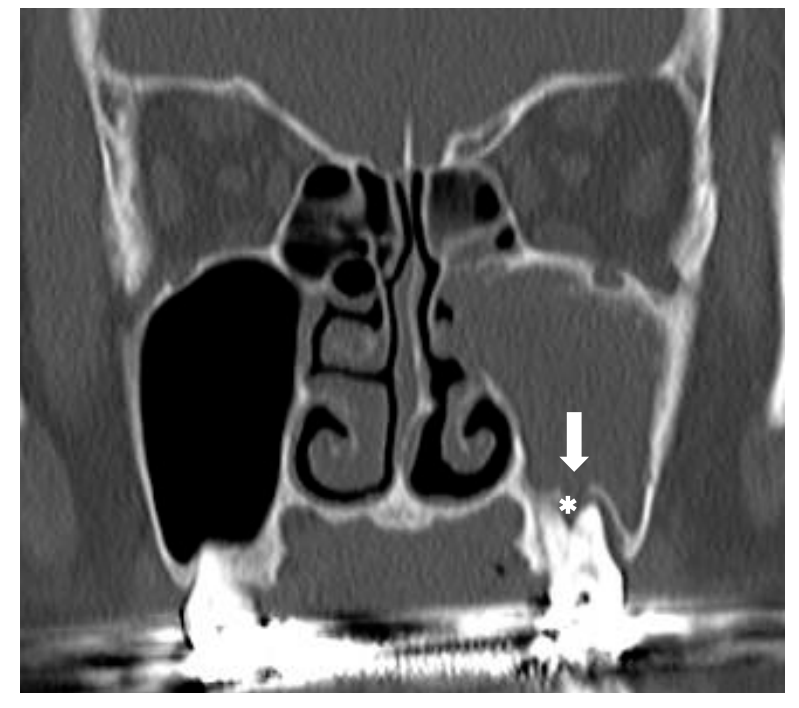

図 5 根尖病巣を伴う骨溶解像 症例：51歳女性, 主訴：悪 臭・鼻閉。左上顎歯の根尖病巣 $(*)$ ならびに上顎骨 の溶解 (矢印) をみとめる。

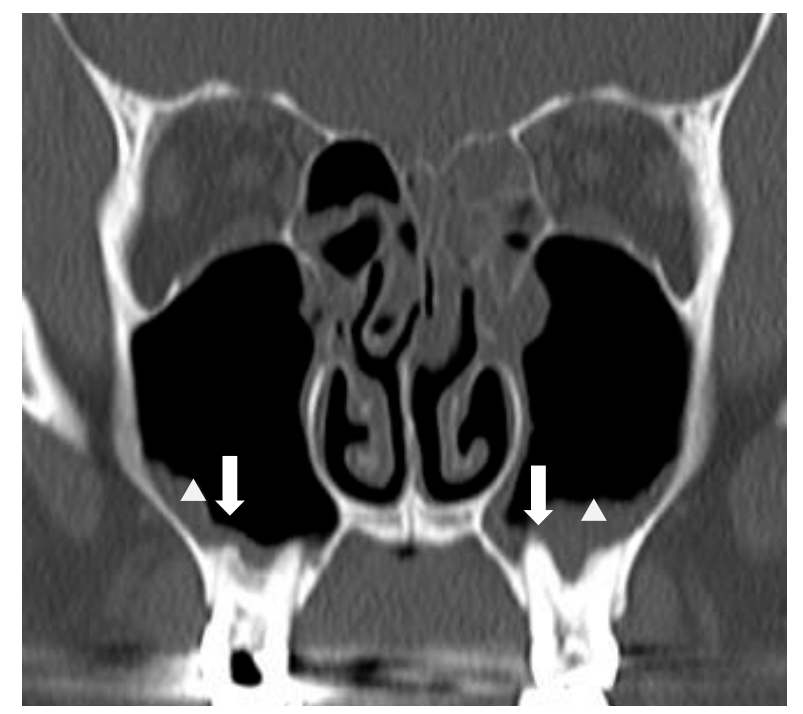

図6上顎洞内への歯根部の突出 症例：50歳女性，主訴： 鼻汁・後鼻漏 - 鼻閉。両側上顎歯の歯根部の上顎洞内 への突出 (矢印) と上顎洞内の粘膜肥厚 $(\boldsymbol{\Delta})$ を認める。

(27.0\%), (3)上顎洞陰影を認めるものは726名 (82.3\%) であった。(1)(2)すべてを満たし，画像上歯性上顎洞炎 と診断された患者は169例（19.1\%)であった（図 8 )。上 顎洞陰影があり，根尖病巣を有しながらも上顎洞との交 通を認めなかった症例，つまり診断基準の(1)と(3)を満た した症例は 27 症例, 32 側 (右17側, 左15側）存在してい た。即ち, 上顎洞陰影を伴った根尖病巣は交通の有無に 関わらず196例 $(169+27)$ 存在した。根尖病巣のある354 例（=１）のうち上顎洞陰影を認めなかったのは158例

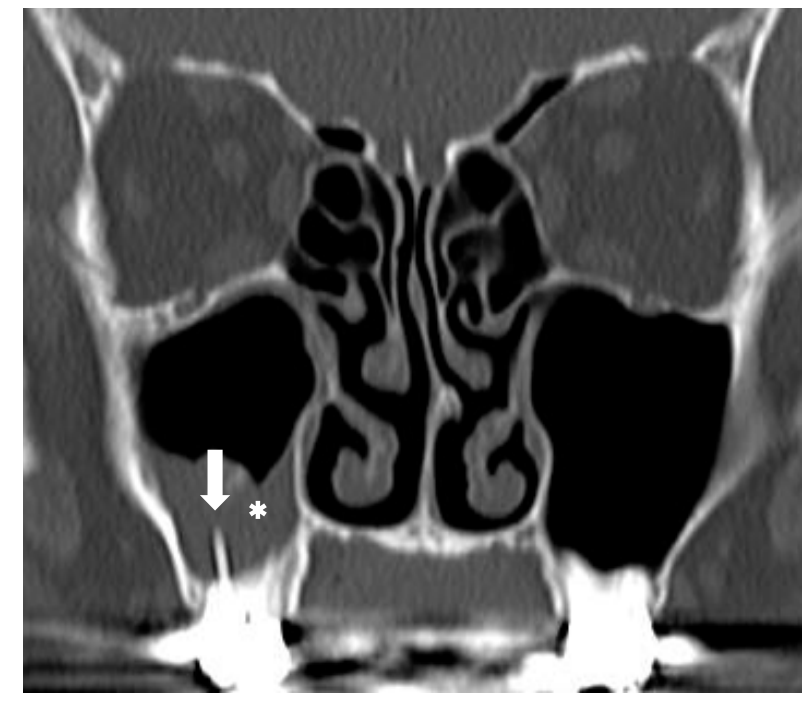

図 7 歯科材料等異物迷入 症例：70歳女性，主訴：鼻汁・ 後鼻漏・右㚘頁部痛。右側上顎洞との交通を有する歯科 材料等異物迷入 (矢印) と同側のみの上顎洞院影 $(*)$ を認める。

(146＋12）だった。更に1,112例のうち, 副鼻腔陰影を認 めなかった残りの230例 $(1112-882)$ の中で根尖病変の み認めたのは11例であり，合計169例（158+11）におい ては上顎歯の根尖病巣を有していながらも上顎洞陰影を 伴わなかった（図 8 )。

歯性上顎洞炎と診断された 169 名のうち, 病側は, 右側 67名 $(39.6 \%)$, 左側 80 例 $(47.3 \%)$, 両側22例 $(13.0 \%)$ であった。患者背景は以下の通りであった。男性 99 例 (58.9\%) 女性70例 $(41.4 \%)$, 平均年齢54.6 1 16.9歳で あった。喫煙歴55例 $(32.5 \%)$ ，アレルギー性鼻炎78例 $(46.1 \%)$, 高血圧 27 例 $(16.0 \%)$, 気管支喘息 22 例 $(13.0 \%)$, 糖尿病10例 $(5.9 \%)$ であった。主訴としては, 鼻汁 89 例 $(52.7 \%)$, 鼻閉85例 $(50.2 \%)$ が多く, 後鼻漏25例 $(14.8 \%)$, 煩部痛 25 例 $(14.8 \%)$, 出血 8 例 $(4.7 \%)$, くしゃみ 6 例 $(3.6 \%)$ ，嗅覚障害 3 例 $(1.8 \%)$ ，無症状 4 例 $(2.4 \%)$ で あった（図 9)。CT施行時点での治療歴は, マクロライ ド療法50例 $(29.6 \%)$ と最も多く, 抗ヒスタミン薬31例 (18.3\%), 点鼻薬20例 $(11.8 \%)$, 抗ロイコトリエン薬19 例 $(11.2 \%)$ であった。原因歯は両側第 1 小臼歯 $\left(4^{\text {th }}\right)$ よ り前方は認めず，両側とも第 1 大臼歯 $\left(6^{\text {th }}\right)$ が最多で あった。内訳としては右側が第 1 小臼歯 3 例 $(0.1 \%)$, 第 2 小臼歯21例 $(23.6 \%)$, 第 1 大臼歯44例 $(49.4 \%)$, 第 2 大曰歯 25 例 $(28.1 \%)$, 第 3 大臼歯 4 例（0.4\%）であっ た。左側は第 1 小臼歯 5 例 $(0.5 \%)$ ，第 2 小臼歯26例 $(25.5 \%)$ ，第 1 大臼歯50例 $(49.0 \%)$ ，第 2 大臼歯29例 $(28.4 \%)$, 第 3 大臼歯 7 例（0.7\%）であった（図10）。歯 性上顎洞炎と診断された症例のうち，受診時に歯科治療 


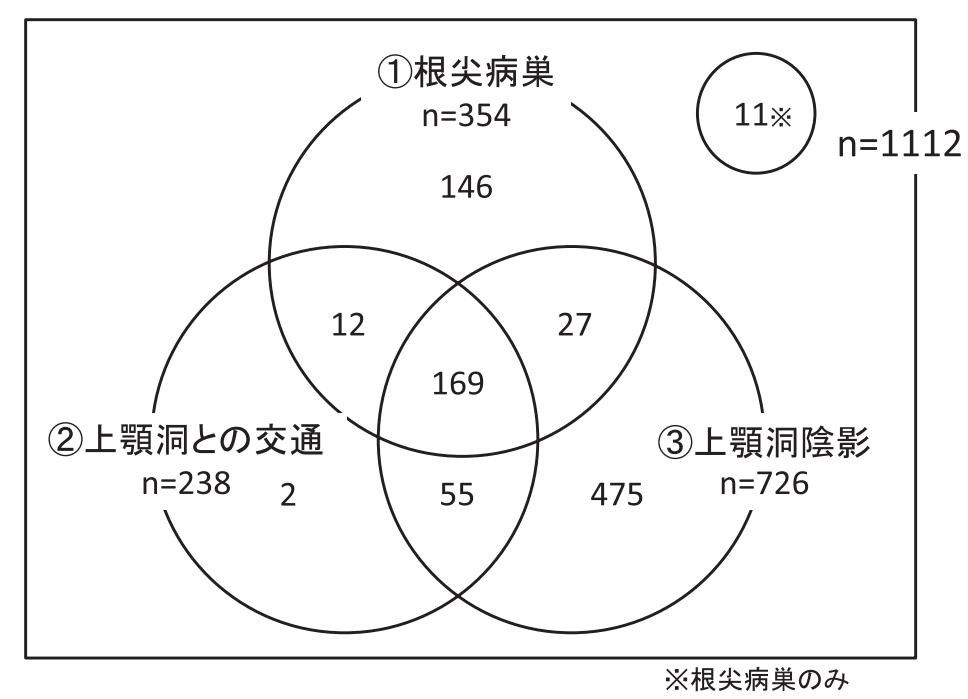

図8 副鼻腔CT施行した1,112例の画像結果

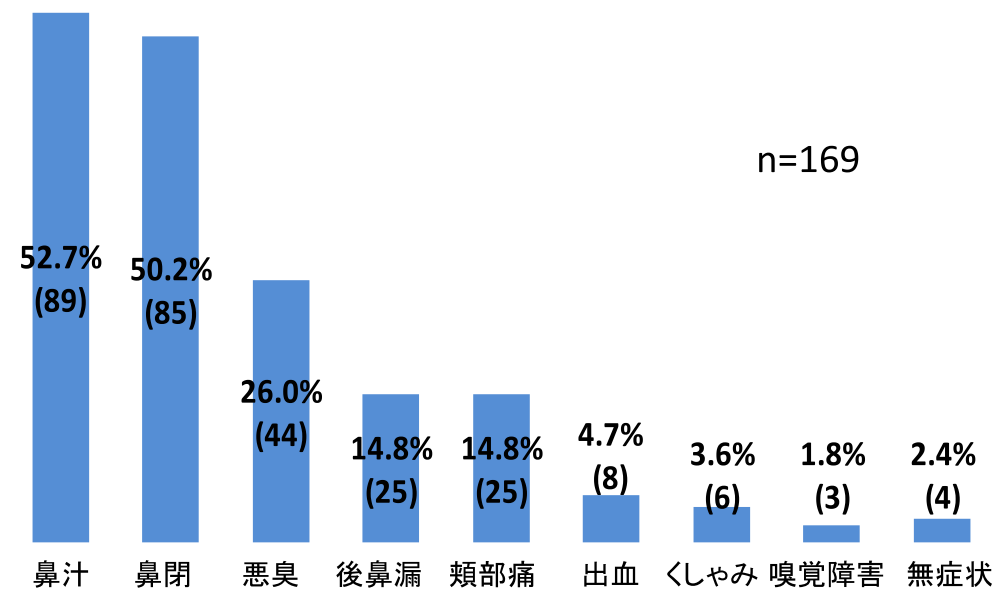

図9 主訴

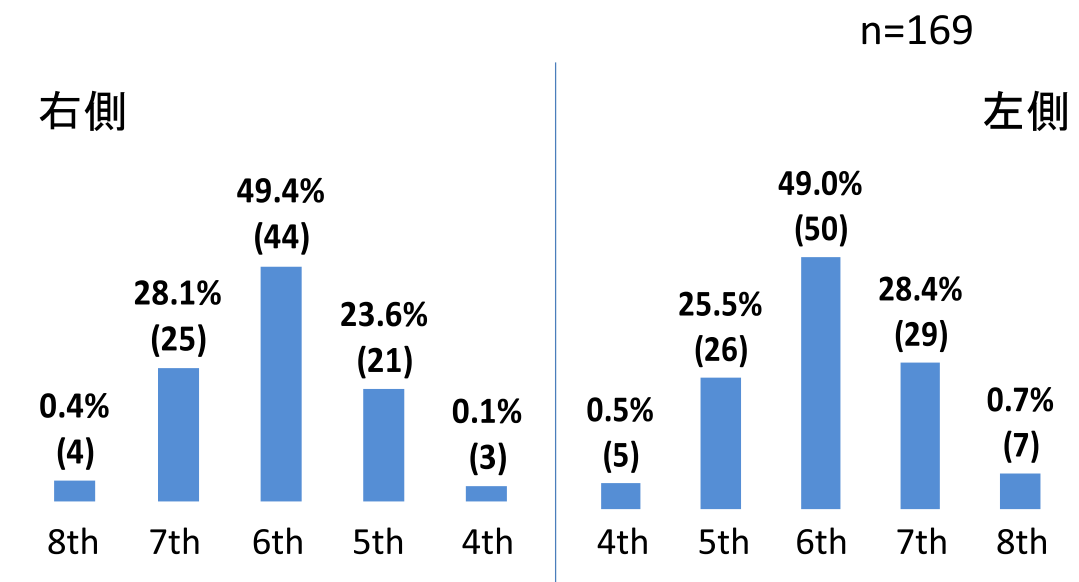

図10 原因歯の内訳 


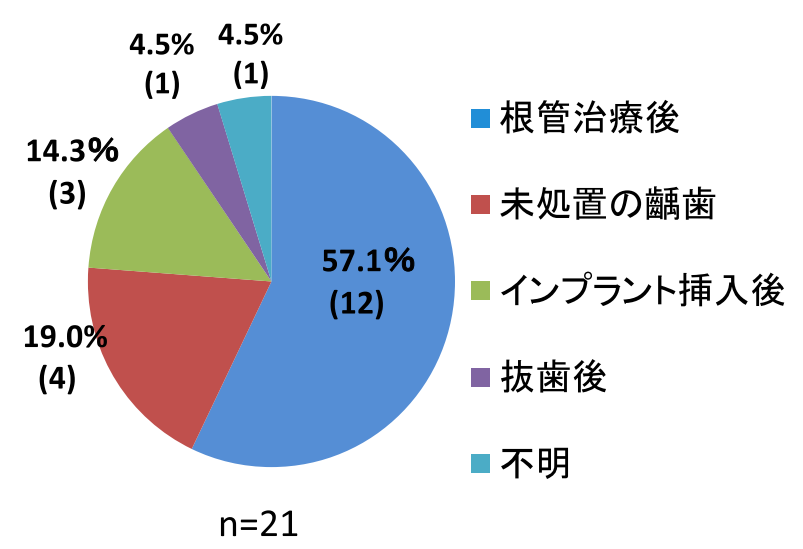

図11受診時に施行されていた歯科治療介入の内訳

介入が確認できた患者は $12.4 \%(21 / 169)$ と少なく, 21 症例中, 根管治療後が 12 例 $(57.1 \%)$, 続いて未処置の齲 歯 4 例 $(19.0 \%)$, インプラント挿入後 3 例 $(14.3 \%)$, 抜 歯後 1 例 $(4.5 \%)$ であった（図11）。

\section{考察}

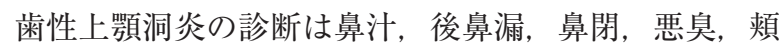
部痛等の臨床症状, 原因歯の存在, 画像診断で総合的に 診断されるが, 今回は画像診断に着目し，詳細な検討を 行った。これまで歯性上顎洞炎の診断には単純X線撮影, 歯科ではパノラマ撮影, 断層撮影が行われてきたが二次 元的把握となり, アーチファクトなどの人工物の影響も 重なるため診断には限界があり必ずしも有用ではなかっ た9)。今日では上顎洞の観察だけでなく，上顎歯の歯根 部・上顎骨も確認でき歯との三次元的位置関係も明瞭に 描出されるためCT検査が最も有用な検査であり ${ }^{10)}$, 日常 的に行われている。CTは我々耳鼻咽喉科医が使用する ヘリカルCTに加え, 近年歯科用Conebeam CTが普及し つつある。Conebeam CTの利点としては装置がコンパ クトであり安価であること, 被爆量が少ないこと, 金属 のアーチファクトが少ないこと，歯冠修復歯と歯周組織 の読影も可能であること, 立位での撮影が可能であるこ となどが挙げられる ${ }^{10)}$ 。欠点としては精度が低く組織学 的変化があまり反映されないこと，画像にノイズが多い こと, 撮影範囲が狭いこと, 軟部組織の評価が困難であ ることなどが挙げられる。

歯性上䫟洞炎では，その原因歯の治療も並列して行う ことが重要である。上顎洞底部は前方に浅く後方に深く 存在し，小臼歯と大臼歯は上顎洞底に存在しているた め, 第 1 小臼歯 $\left(4^{\text {th }}\right)$ から第 3 大臼歯 $\left(8^{\text {th }}\right)$ に発症した 根尖病巣の炎症が波及しやすい位置関係をなしている。 今回の結果からも原因歯は第 1 小臼歯 $\left(4^{\text {th }}\right)$ より前方に
存在することは稀であることが分かった（インプラント は除く)。また根尖が上顎洞内に突出している比率が最 も高いのは第 1 大臼歯 $\left(6^{\text {th }}\right)$ で ${ }^{1)}$, 病変は片側のみならず 両側でも存在していた。

歯性上顎洞炎になる経緯として最も多いのは歯性感染 症からの炎症が，まず上顎洞底部の繊毛上皮の機能障害 を引き起こす。この時点でCTを撮影すると, 上顎洞底部 の粘膜肥厚像が示される。その後, 上顎骨と歯槽骨の間 に存在するシュナイデル膜に感染がおよび, さらに歯髄 の炎症が高度であると根尖性歯髄炎となり, その結果, 上顎骨との間に穿孔をおこし歯性上顎洞炎が悪化す る 2 .7)。ただし，上顎洞との交通をきたす症例もあれば， シュナイデル膜を穿孔せず上顎洞に粘膜肥厚のみを残す

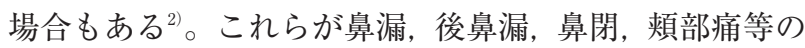
症状をきたすようになると臨床的に歯性上顎洞炎と診断 する。更に，歯性上顎洞炎発症の危険因子として，上顎 洞底線が低位であり上顎臼歯根尖と近接していることが 指摘されている ${ }^{11)}$ 。まり，根尖病巣を有していても上 顎洞陰影を伴わないのは，上顎洞底線が比較的高位であ り上顎臼歯根尖までの距離が比較的保たれており，上顎 洞炎に至らないためと予想される。

歯性上顎洞炎の臨床症状は，上顎洞の炎症のため粘膜 肥厚や膿汁分泌をおこすため鼻漏と後鼻漏が中心とな る ${ }^{12)}$ 。鼻閉や㚘部痛はその次に多いとされ ${ }^{3)}$, 重症の場合 には高度の悪臭や疼痛を伴う ${ }^{1)}$ 。今回の検討結果からも 煩部痛の症状を認めたのは $14.8 \%$ であった。このため, 煩部痛を来していなくても画像上歯性上顎洞炎は存在 し, 病態が進行することでいずれ症状が出現してくる可 能性がある。実際，今回の調査では 4 例の無症状例が存 在しており，患者の自覚症状のみならず，画像にて客観 的に評価を行い，歯科依頼を検討する必要がある。しか しながら今回の検討で画像的に歯性上顎洞炎と診断され た169例のうち, 歯科治療を受けていた患者は12.4\%（21 例）と少なく，原因歯がありながら治療介入がなされず 経過することも少なくないと予想される。根尖病巣は適 切に除去されないと急性増悪を生じうる。また，無治療 で放置されると歯根襄胞に移行するか，もしくは持続的 に病巣が存在し, 将来的には臨床症状を伴うようになる 可能性がある ${ }^{9,17)}$ 。

原因歯の保存が可能であれば，不必要な抜歯を回避 することもでき，患者の生活の質を保つことができる。 我々耳鼻咽喉科医も，画像診断時には副鼻腔陰影に加え て上顎歯の根尖病巣の有無についても確認し, 歯科治療 介入を促すことが望まれる。今回の結果を受けて当施設 では, 副鼻腔 $\mathrm{CT}$ 上陰影の有無に関わらず, 根尖病巣を認 
めた症例に対しては，放置されれば病態の悪化や耳鼻科 的治療の介入があっても将来的には感染を繰り返す可能 性が高い為, 見つけた時点で歯科的診断治療の有無の確 認を行い，その必要性を患者に促している。同時に，鼻 症状と上顎洞陰影を認めた症例に対しては通常の副鼻胿 炎としてのマクロライド療法を継続し, 保存的加療に効 果がない場合には内視鏡下鼻内手術を促すようにしてい る。しかし歯科側からの一定した見解がなかったり，歯 科から抜歯が必要と判断されても患者が希望しなかっ たり，治療は一筋縄ではいかないことも多い。

また，昨今慢性副鼻腔炎の病態は，非好酸球性副鼻腔 炎や好酸球性副鼻腔炎など多梯性が指摘されている。歯 性上顎洞炎は，単独で存在することもあれば非好酸球性 や好酸球性の副鼻腔炎に合併することもあり，慢性副鼻 腔炎の多様性や難治性の交絡因子の一つとして位置づけ られると考元る。今回画像的に歯性上䫟洞炎と䛦断され た169例の治療経過，および根尖病巣を有していながら も歯性上顎洞炎の診断に至らなかった196例の経過を追 うことで, 歯性上顎洞炎の治療戦略を構築していくこと が今後の課題と考える。

\section{まとめ}

1 ）画像上，歯性上顎洞炎と診断された症例の疫学調查 を行った。

2) 根尖病巣を有していながらも, 歯科での治療介入が なされていないケースが存在する。

3 ）根尖病巣は放置されると, 歯性上顎洞炎を惹起した り，歯性上顎洞炎の遷延化を来したりする可能性があ るため, 画像診断時に副鼻腔陰影ならびに上顎歯の根 尖病巣の有無についても確認することが望まれる。

2015年10月 広島国際会議場における第54回日本鼻科 学会にて発表した。

\section{参考文献}

1 ）高橋雅幸：歯性上顎洞炎の診断と治療. 日歯先技研 会誌 $2009 ； 15: 64-69$.

2) Itzhak Brook : Sinusitis of odontogenic origin. Otolaryingology-Head and Neck Surgery 2006 ; 135 : 349-355.

3 ）金子 功, 原田宏一, 石井豊太, 他：歯性上顎洞炎 症例の臨床的検討. 日耳鼻 $1990 ; 93: 1034-1040$.

4 ) 中山次久, 真崎正美, 宮崎日出海 : 歯科インプラン 卜治療に伴う上顎洞炎。耳展 2010；53：234-238.

5 ) 高橋伸夫：歯性上顎洞炎の原因歯は抜歯するのか? 日本歯科評論 $2004 ; 64: 74-79$.

6 ）佐藤公則：歯性上顎洞炎の病態と内視鏡下鼻内手術 の有用性. 日耳鼻 $2001 ; 104: 715-720$.

7 ）佐藤公則：歯性上顎洞炎. ENTONI $2011 ； 131 ： 65-$ 72.

8 ）尾尻博也:耳鼻咽喉科領域の画像評価. 日耳鼻 2013; 116 : 1083-1092.

9 ）佐藤公則：修復治療に伴う歯性上顎洞炎. 日耳鼻 $2014 ; 117$ : 809-814.

10）佐藤公則：Conebeam CTによる歯性上顎洞炎の診 断. 耳展 $2007 ; 50: 214-221$.

11）東 博二, 細井裕司，木村裕毅，他：歯性上顎洞炎 の臨床的検討. 耳鼻臨床 $1991 ； 61-67$.

12）吉田拓人, 浅香大也, 中山次久, 他：片側性副鼻腔 炎の自覚症状についての検討.耳展 $2012 ; 55: 434$ 439.

13）鈴木二郎：根管処置前後の歯根肉芽腫由来線維芽細 胞様細胞の動態. 神奈川歯学 $1992 ； 27-1 ： 18-29$. 